\title{
PREVALENCE OF METACERCARIAL INFECTION IN SOME MARKETED FISH IN GIZA GOVERNORATE, EGYPT BY
}

\author{
SAAD M. SAAD ${ }^{1}$, AMANI M. SALEM ${ }^{1}$, OLFAT A. MAHDY ${ }^{2}$, \\ AND EID SAYED IBRAHIM ${ }^{3^{*}}$
}

Department of Food Control, Faculty of Veterinary Medicine, Benha University ${ }^{1}$, and Department of Parasitology, Faculty of Veterinary Medicine, Cairo University ${ }^{2}$, Egypt, Parasitology Unit, Public Health Pests Laboratory of Jeddah Governorate, Saudi Arabia $^{3}$ ( ${ }^{*}$ Correspondence: Agyad2014@yahoo.com)

\section{Abstract}

A total of 180 Oreochromis niloticus and 120 Clarias gariepenus of different weight and length were randomly collected from three different markets (El-Moneib, El-Ayiat and El-Badrashin) in Giza Governorate from January to June 2012. Muscles and organs of the fishes were examined for infective zoonotic parasites. The total prevalence of encysted metacercariae (EMC) among examined O. niloticus was $82.8 \%$, the highest prevalence was in the tail $(75 \%)$, while the lowest one $(17 \%)$ in skin, and in the gills was $(57.2 \%)$. Total prevalence of EMC was $35.8 \%$ in the C. gariepenus, the highest was in trunk $(27.5 \%)$, then head \& tail $(25.8 \% \& 25 \%)$ and the lowest one $(4.1 \%)$ was in the skin but none in the gills. There was an indirect relationship between the EMC prevalence and the fishes weight and length. The recovered EMC from O. niloticus were; Diplostomatidae, Cyathocotylide and Heterophyidae. Besides, Cyanodiplostomatidae and Cyathocotylide were recovered from $C$. gariepenus. These EMC were successfully developed to adults after experimental infection to pigeons and rats. The emerging adult flukes were Prohemistomum vivax, Mesostephanus appendiculatus and Centrocetus armatus.

Key words: Freshwater fishes, Clarias gariepinus, Oreochromis niloticus, Zoonotic trematodes, EMC.

\section{Introduction}

The expansions in the production of fishes from both natural water resources and fish cultures have been widely spread all over the world to compensate the shortage of good quality animal protein. So , as fish considered one of the most valuable nutritive ,tasty palatable and easily digested protein ,it also act as host for many parasitic diseases which may be harmful for man and fish eating mammals if it consumed raw or lightly cocked (El- Naffar et al, 1985). The consumption of encysted metacercariae developed diseases to human consumer (Hernandez et al, 1998). The WHO (1995) estimated that the number of people currently infected with fish-borne parasite trematodes exceed 18 million, but worldwide the number of people at risk, including those in developing country is more than half a billion (Chai et $a l, 2005)$. In Egypt, metacrcarial infections are the main larval digenean causing severe economic loss among fishes in both open water resources and fish culture. Also, many of metacercaria in fish have public health importance (Park et al, 2009). In Egypt, the endemic of encysted metacercarial infection in Oreochromis niloticus and Clarias gariepenus fishes were reported (Abdallah et al, 2009).

The present study, clarified the role of $\mathrm{Or}$ eochromis niloticus and Clarias gariepenus as a source of parasitic infection of public health importance.

\section{Material and Methods}

A total of 300 fishes (180 O. niloticus and 120 C. gariepenus) of different weight and length were randomly collected from three different located markets (El-Moneib, ElAyiat and El-Badrashin) in Giza Governorate from January to June 2012. The collected fishes were put in ice-boxes, and immediate transported to the laboratory.

They were identified by species, and then weight and length were determined. They were clinical examined (Burgess et al, 1999). 
Table 1: Number and average weight of fishes.

\begin{tabular}{|l|l|l|}
\hline Fish weight & O. niloticus & C. gariepenus \\
\hline$<50 \mathrm{gm}$ & 81 & 0 \\
\hline $50-100 \mathrm{gm}$ & 65 & 12 \\
\hline $100-150 \mathrm{gm}$ & 11 & 45 \\
\hline $150-200 \mathrm{gm}$ & 13 & 13 \\
\hline $200-250 \mathrm{gm}$ & 10 & 16 \\
\hline $250-300 \mathrm{gm}$ & 0 & 25 \\
\hline $300-400 \mathrm{gm}$ & 0 & 9 \\
\hline Total & 180 & 120 \\
\hline
\end{tabular}

Table 2: Number and average length of fishes.

\begin{tabular}{|l|c|c|}
\hline Length & O. niloticus & C. gariepenus \\
\hline$<10 \mathrm{~cm}$ & 7 & 0 \\
\hline$>10-15 \mathrm{~cm}$ & 126 & 2 \\
\hline$>15-20 \mathrm{~cm}$ & 31 & 2 \\
\hline$>20-25 \mathrm{~cm}$ & 16 & 34 \\
\hline$>25-30 \mathrm{~cm}$ & 0 & 44 \\
\hline$>30-35 \mathrm{~cm}$ & 0 & 35 \\
\hline$>35-4 \mathrm{~cm}$ & 0 & 3 \\
\hline Total & 180 & 120 \\
\hline
\end{tabular}

Macroscopical examination was done (Mahdy et al, 1995) to detect any abnormalities using a hand lens. Microscopic examination was done after compression between 2 slides, fixation and staining (Garcia, 2001) to detect EMC lodged in/or attach to different organs and tissues, which were gently removed (Srisawangwong et al, 1997).

Clean laboratory bred ten rats of 3-weeks old males and ten pigeons of 2-weeks old males were divided into 2 groups of 5 each. G1 was fed on EMC isolated from $O$. niloticus and $\mathrm{G} 2$ was fed on EMC from $C$. gariepenus (Tab. 3). G3 included 2 rats and 2 pigeons without infection as control negative group. All were kept in separate cages under laboratory conditions.

Stool samples from the three groups were daily examined after being processed for trematode eggs to determine the prepatent periods. On detection of characteristic eggs in feces of experimented with rats and/or pigeons, they were sacrificed and dissected out carefully to recover the adult worms. The small intestine was subdivided into three parts (anterior, middle and posterior) and each part was separately opened. The contents and scraped mucosa of each region were collected in suitable jars containing normal saline, and washed several with normal saline to remove coarse particles of intestinal contents and mucous attached to the worms. Sediments were examined under a binocular microscope; the detected trematodes were collected in normal saline, counted and then picked up by Pasteur pipette in a $10 \%$ formalin small bottle.

Adult worms and encysted metacercariae were processed for permanent preparation (Pritchard and Kruse, 1982), and identifications (Yamaguti, 1971).

\section{Results}

The results were given in tables $(3,4,5,6,7$ $\& 8)$ and figures $(1,2,3,4,5,6 \& 7)$.

Table 3: Infection of rats and pigeons with EMC from Oreochromis niloticus and Clarias gariepenus

\begin{tabular}{|l|c|c|c|c|}
\hline Fish & EMC site & Type of EMC & Rats EMC dose & Pigeons EMC dose \\
\hline \multirow{2}{*}{ G1: O.niloticus } & Muscles & Cyathocotylide \& Diplostomatide & 500 & 500 \\
\cline { 2 - 5 } & Gills & Cyathocotylide \& Heterophyide & 500 & 500 \\
\hline G2: C. gariepenus & Muscles & Cyathocotylide \&Cynodiplostomatide & 1200 & 1200 \\
\hline
\end{tabular}

Table 4: Prevalence of different types of recovered EMC from examined fish species.

\begin{tabular}{|l|c|c|c|c|}
\hline Fish species & No. examined & No. infected & $\%$ & Recovered EMC from examined fish \\
\hline O. niloticus & 180 & 149 & 82.8 & Diplostomatidae, Cyathocotylidae, Heterophyidae \\
\hline C. gariepenus & 120 & 43 & 35.8 & Cyathocotylidae, Cynodiplostomatidae \\
\hline Total & 300 & 192 & 64.0 & Four types \\
\hline
\end{tabular}


Table 5: Prevalence and distribution of EMC in examined fishes.

\begin{tabular}{|l|l|l|l|l|l|l|}
\hline Fish species & \multicolumn{3}{|l|}{ Oreochromis niloticus } & \multicolumn{3}{l|}{ Clarias gariepenus } \\
\hline \multirow{2}{*}{ Infection site } & No. examined & No. infected & $\%$ & No. examined & No. infected & $\%$ \\
\cline { 2 - 7 } & 180 & 149 & 82.8 & 120 & 43 & 35.8 \\
\hline Tail & 180 & 135 & 75.0 & 120 & 30 & 25.0 \\
\hline Trunk & 180 & 99 & 55.0 & 120 & 33 & 27.5 \\
\hline Head & 180 & 87 & 48.3 & 120 & 31 & 25.8 \\
\hline Gill & 180 & 103 & 57.2 & 120 & 0 & 0 \\
\hline Skin & 94 & 16 & 17.0 & 120 & 5 & 4.1 \\
\hline Eye & 94 & 37 & 39.4 & 120 & 14 & 11.7 \\
\hline
\end{tabular}

Table 6: Statistical analysis of EMC number in examined fishes.

\begin{tabular}{|l|l|c|c|c|}
\hline Examined parts or organs & Type of fish & Minimum & Maximum & M \pm SD \\
\hline \multirow{3}{*}{ Tail } & O. niloticus & 4 & 700 & $35.42 \pm 69.49$ \\
\cline { 2 - 5 } & C. gariepenus & 3 & 400 & $22.72 \pm 71.99$ \\
\hline \multirow{3}{*}{ Head } & O. niloticus & 1 & 700 & $14.14 \pm 57.57$ \\
\cline { 2 - 5 } & C. gariepenus & 1 & 350 & $13.45 \pm 48.53$ \\
\hline \multirow{3}{*}{ Gill filament } & O. niloticus & 3 & 700 & $13.75 \pm 56.57$ \\
\cline { 2 - 5 } & C. gariepenus & 1 & 300 & $12.21 \pm 41.16$ \\
\hline \multirow{2}{*}{ Skin } & O. niloticus & 1 & 6 & $1.16 \pm 1.30$ \\
\cline { 2 - 5 } & C. gariepenus & 0 & 0 & $0.00 \pm 0.00$ \\
\hline \multirow{2}{*}{ Eye* } & O. niloticus & 1 & 80 & $2.91 \pm 10.70$ \\
\cline { 2 - 5 } & C. gariepenus & 2 & 50 & $0.66 \pm 4.75$ \\
\hline & O. niloticus & 1 & 200 & $9.86 \pm 27.33$ \\
\cline { 2 - 5 } & C. gariepenus & 4 & 150 & $2.93 \pm 15.63$ \\
\hline
\end{tabular}

*significant, $\mathrm{p}$ value $\leq 0.05$ between number of EMC in O. niloticus and C. gariepenus

Table 7: Frequency distribution of EMC in relation to weight of examined fishes

\begin{tabular}{|l|c|c|c|c|c|c|}
\hline \multirow{2}{*}{ Fish } & \multicolumn{3}{|c|}{ O. niloticus } & \multicolumn{3}{c|}{ C. gariepenus } \\
\cline { 2 - 7 } & No. examined & No. infected & $\%$ & No. examined & No. infected & $\%$ \\
\hline$<50 \mathrm{~g}$ & 81 & 77 & 95.1 & - & - & - \\
\hline $50<100 \mathrm{~g}$ & 65 & 57 & 87.7 & 12 & 5 & 41.7 \\
\hline $100<150 \mathrm{~g}$ & 11 & 8 & 72.7 & 45 & 18 & 40 \\
\hline $150<200 \mathrm{~g}$ & 13 & 6 & 46.2 & 13 & 3 & 23.1 \\
\hline $200<250 \mathrm{~g}$ & 10 & 1 & 10 & 16 & 4 & 25 \\
\hline $250<300 \mathrm{~g}$ & - & - & - & 25 & 12 & 48 \\
\hline $300<400 \mathrm{~g}$ & - & - & - & 9 & 1 & 11.1 \\
\hline
\end{tabular}

Table 8: Frequency distribution of EMC in relation to length of fishes.

\begin{tabular}{|l|c|c|c|c|c|c|}
\hline \multirow{2}{*}{ Length } & \multicolumn{3}{|c|}{ Oreochromis niloticus } & \multicolumn{3}{c|}{ Clarias gariepenus } \\
\cline { 2 - 7 } & No. examined & No. infected & $\%$ & No. examined & No. infected & $\%$ \\
\hline$<10 \mathrm{~cm}$ & 7 & 6 & 85.7 & - & - & - \\
\hline $10<15 \mathrm{~cm}$ & 126 & 118 & 93.7 & 2 & 1 & 50 \\
\hline $15<20 \mathrm{~cm}$ & 31 & 20 & 64.5 & 2 & 2 & 100 \\
\hline $20<25 \mathrm{~cm}$ & 16 & 5 & 31.3 & 34 & 12 & 35.3 \\
\hline $25<30 \mathrm{~cm}$ & - & - & - & 44 & 16 & 36.3 \\
\hline $30<35 \mathrm{~cm}$ & - & - & - & 35 & 12 & 34.3 \\
\hline $35<40 \mathrm{~cm}$ & - & - & - & 3 & 0 & 0 \\
\hline
\end{tabular}

Table 9: Infection of rats and pigeons with EMC from $O$. niloticus and $C$. gariepenus:

\begin{tabular}{|c|c|c|c|c|}
\hline \multirow{2}{*}{\multicolumn{2}{|c|}{$\begin{array}{l}\text { Group No. } \\
\text { Types of EMC }\end{array}$}} & \multicolumn{2}{|l|}{ G1 (EMC from $O$. niloticus) } & \multirow{2}{*}{$\begin{array}{l}\mathrm{G} 2 \text { (C. gariepenus) } \\
\text { Cyathocotylidae Cynodiplostomatidae }\end{array}$} \\
\hline & & Cyathocotylidae, Diplostomatidae & Cyathocotylidae, Heterophyidae & \\
\hline \multirow{5}{*}{ Rat } & No. Examined & 2 & 2 & 2 \\
\hline & Dose of EMC & 500 & 500 & 1200 \\
\hline & No. infected & 2 & 2 & 2 \\
\hline & recovered flukes & 360 & 30 & 930 \\
\hline & Recovery rat & $36 \%$ & $3 \%$ & $38.75 \%$ \\
\hline \multirow{5}{*}{$\begin{array}{l}\mathrm{Pi}- \\
\text { geo } \\
\mathrm{n}\end{array}$} & No. Examined & 2 & 2 & 2 \\
\hline & Dose of EMC & 500 & 500 & 1200 \\
\hline & No. infected & 2 & 0 & 2 \\
\hline & recovered flukes & 110 & 0 & 600 \\
\hline & Recovery rat & $11 \%$ & 0 & $25 \%$ \\
\hline \multicolumn{2}{|c|}{$\begin{array}{l}\text { Identification of recov- } \\
\text { ered Fluke }\end{array}$} & $\begin{array}{l}\text { Prohemistomum vivax } \\
\text { Mesostephanus appendiculatus }\end{array}$ & $\begin{array}{l}\text { Centrocetus armatus } \\
\text { Prohemistomum vivax } \\
\text { Mesostephanus appendiculatus }\end{array}$ & $\begin{array}{l}\text { Prohemistomum vivax } \\
\text { Mesostephanusappendiculatus }\end{array}$ \\
\hline
\end{tabular}




\section{Discussion}

In the present study, the overall EMC infection was $64.0 \%$. These were $82.2 \%$ and $35.8 \%$ in $O$. niloticus and C. gariepenus, respectively. The highest one was $(75.0 \%$ \& $27.5 \%$ ) in tail and trunk region, respectively. The lowest was found in skin $(17.0 \%$ \& $4.1 \%$ ), respectively. There was a significant difference in number of EMC between the gill filament, skin and muscles of $O$. niloticus and C. gariepenus $(\mathrm{p}<0.05)$ but without significant difference in number of EMC recovered from head, trunk and tail of $O$. niloticus and C. gariepenus ( $\mathrm{p}>0.05$ ).

In the present study, O. niloticus weight, prevalence of EMC was higher (95.1\%) in weight less than $50 \mathrm{gm}$. Lowest one (10.0\%) in fishes ranged from $(200-250 / \mathrm{g})$. The highest prevalence of EMC (48.0\%) was in fishes' weight from $(250-300 / \mathrm{g})$ in C. gariepenus, but the lowest (11.1\%) was in fishes' weight from (300-400/gm). The O. niloticus \& $C$. gariepenus highest prevalence of EMC was $(93.7 \%$ \& $100 \%)$ in length (10$1 \mathrm{~cm} \& 15-20 \mathrm{~cm})$, while lowest one was $(31.3 \%$ \& $0.0 \%)$ was in length from (20-25 $\mathrm{cm} \& 35-40 \mathrm{~cm})$.

In the present study, the EMC recovered were Cyathocotylide, Cynodiplostomatidae, Heterophyidae and Diplostomatidae metacercariae recovered from muscles and gills from of examined $O$. niloticus and $C$. gariepenus. By experimental infection trematodes recovered were Centrocetus armatus, Mesostephanus appendiculatus and Prohemistomum vivax.

In the present study, the overall detected EMC in infected $O$. niloticus was $(82.2 \%)$ for the totally examined fish. These results agreed with Abo-Esa and Shaheed (2003) who recorded infection of $80 \%$. But, the present results were more or less high than that reported by Abu-El-Ezz et al. (2000) and Elsheikha and Elshazly (2008), which were $74.33 \% \& 23.2 \%$ respectively. The detected EMC was (35.8\%) in C. gariepenus. This result was lower than those reported by El-Gohry and Samah (1996), and Saleh et al. (2009), which were $68 \%$ \& $87.1 \%$ respectively. These differences might be related to the water sources of the studied fishes, habitat whether rural or urban and/or the seasonal time of fishes' collection..

In the present study, highest number of EMC in O.niloticus was detected in the posterior body third or tail region $(75 \%)$ followed by the middle third $(55 \%)$ and the lowest was in the anterior third (48.3\%) with the lowest number in the skin (17\%). In $C$. gariepenus the number of EMC was $25.8 \%$ in head region, $27.5 \%$ in trunk and $25 \%$ in tail muscles without EMC in gills. These results agreed with El-Naffar and El-Shahawy (1986) and Mahmoud and Sahlab (1993).

In the present study, the highest average number of EMC in $O$. niloticus was in muscles of tail region $(35.42 \pm 69.49) / \mathrm{g}$ followed by trunk region $(14,14 \pm 57,57)$ and lastly head region $(13,75 \pm 56,57)$. Average numbers of EMC in different organs were $(1.16 \pm 1.30) / \mathrm{gm}$ gill filament, $(2.91 \pm 10.7) /$ gm skin, and (9.86 \pm 27.33$) / e y e$. The result agreed with Mahmoud and Sahlab (1993), but disagreed with Waheb and Abo-Esa (2002) and Taher (2009). In C. gariepenus, highest EMC average numbers were detected in tail muscles $(22.72 \pm 71.99) / g m$, followed by trunk muscles $(13.45 \pm 48.53) / \mathrm{gm}$ and head muscles $(12.21 \pm 41.16) / \mathrm{gm}$. EMC average number was $(0.66 \pm 4.75) / g m$ in skin and $(2.93 \pm 15.63) /$ eye but, none in gills. These results differed from those recorded by Saleh et al. (2009). There was a significant difference of the number of EMC between (gill filament, skin and eye) of $O$. niloticus and C. gariepenus $(\mathrm{p}<0.05)$, without significant difference in number of EMC between head, trunk \& tail in $O$. niloticus and $C$. gariepenus. Variation in number and pattern of EMC distribution might be due to size difference and/or immunological response.

In the present study, number of EMC and weight and length of $O$. niloticus \& C. gariepenus, EMC was higher $(95.1 \%$ \& $48.0 \%)$ in weight less than $50 \mathrm{gm} \& 250-300 / \mathrm{gm}$ and 
the EMC in relation to length was $(93.7 \%$ \& $100 \%)$ ) in fish with length ranged from (10$15 \mathrm{~cm} \& 15-20 \mathrm{~cm})$. These results more or less agreed with El-Bouhy et al. (1988).

In the present study, the EMCs were Diplostomatidae, Heterophyidae, Cyathocotyli$d e$ and Cynodiplostomatidae recovered from muscles and gills of $O$. niloticus and $C$. gariepenus. The EMCs were previously recorded from the same fish spp. in Manzala Lake and River Nile in Upper Egypt by Mahdy et al, (1995) and Mousa et al. (2000) respectively. The trematodes recovered were Prohemistomum vivax, Mesostephanus appendiculatus from small intestine of rats and pigeons and Centrocetus armatus, from small intestine of rats. These results agreed with Mahdy et al. (2000), Saleh et al. (2009) and Abu El- Ezz et al. (2000).

In the present study, $P$. vivax and $M$. appendiculatus adult worms were detected in infected pigeons and rats with EMC from muscles of examined fish species. This result agreed with Saleh et al. (2009). Paperna (1980 and Abo-Shady (1980) recorded P. vivax in both man and animals and Williams and Jones (1976) reported fatal zoonotic infection due to $M$. appendiculatus. Besides, El-Azazy et al. (2015) in Kuwait recovered $M$. appendiculatus from stray cats and concluded that cats are good indicators of fishborne trematodes in the environment.

In the present study, adult of Centrocetus armatus were obtained from small intestine of experimentally infected rats with EMC from the gills of examined $O$. niloticus. This result agreed with Abu El-Ezz et al. (2000). Hong et al. (1988) in Korea detected the first human zoonotic $C$. armatus and Chai and Lee (1990) stated that the $C$. armatus have been proven to be the main source of zoonosis by eating raw infected fish.

\section{Conclusion}

The presence of four types of encysted metacercariae from fishes used for human consumption is risky health problem. This is especially true with consumption of raw or insufficiently cooked fishes.

\section{References}

Abdallah, KF, Hamadto, HH, El-Hayawan, IA, Dawoud, HA, Negm-Eldin, M, et al, 2009: Meta-cercariae recovered from fresh-water fishes in the vicinity of Qualkyobia Governorate, Egypt. J. Egypt. Soc. Parasitol. 39, 2:467-77.

Abo-Esa, JFK, Shaheed, IB, 2003: Studies on parasitic larval stages affecting Oreochromis niloticus in two different localities in Egypt. Egypt, J. Comp. Clin. Path. 16, 1:14-29.

Abou-Shady, AF, 1980: Intestinal helminthes of dogs in Egypt. J. Egypt. Med. Assoc. 21, 3: 118-22.

Abu El-Ezz, NMT, Tantawy, EA, Mahdy, O A, El-Massry, AA, 2000: Studies on Heterophyid infections among some fishes in Egypt. Egypt. J. Vet. Sci., 34:11-29.

Burgess, P, Bailey, M, Exell, A, 1999: A - Z of Tropical Fish Diseases and Health Problems: Signs, Diagnosis, Causes, Treatment for Tropical Freshwater Fish. John Wiley \& Sons, Inc.

Chai, J, Lee, SH, 1990: Intestinal trematodes of humans in Korea: Metagonimus, Heterophyids and Echinostome. Korean J. Parasitol. 28: S103-22.

Chai, J, Murrell, D, Lymbery, A, 2005: Fishborne parasitic zoonoses: Status and issues. Inter. J. Parasitol. 35, 11/12:1233-54

El-Naffar, MK, El-Shahawy, GA, 1986: Studies on the metacercriae of the Nile fishes at ElMinia Province. Assiut Vet. Med. J. 15, 30:4754.

El-Azazy, OM, Abdou, NE, Khalil, AI, Al-Batel, MK, Majeed, QA, et al, 2015: Potential zoonotic trematodes recovered in stray cats from Kuwait Municipality, Kuwait. Korean J. Parasitol. 53, 3:279-87.

El-Bouhy, ZM, Saleh, G, El- Desouky, EA, Ali, AA, 1988: Studies on yellow grub infestation in Nile catfish (Clarias Lazera) in Sharkia Province, Zagazig. Vet. J. 17, 2:166-86.

El-Gohary, AH, Samah, IA, 1996: Oreochromis spp. and Clarias lazera as a source of transmitting encysted metacercariae to man. Int. J. Anim. Sci. 11, 2:417-21

El-Naffar, MK, MF, Saoud, IM, Hassan, 1985: Role played by fish in transmitting some trematodes of dogs and cats at Aswan Province, A.R.E. Assiut Vet. Med. J. 14, 27:57-67.

El-sheikha, HM, Elshazly, AM, 2008: Hostdependent variations in the seasonal prevalence and intensity of heterophyid encysted metacer- 
cariae (Digenea: Heterophyidea) in brackish water fish in Egypt. Vet. Parasitol. 153, 1/2:65-72.

Garcia, LS, 2001: Diagnostic Medical Parasito$\operatorname{logy}\left(4^{\text {th }}\right.$ edition). ASM Press, Washington, DC.

Hernandez, EM, Constantino, C, Gracia, M, Osorlo, SO, 1998: Gill lesions in common carp, Cyprinus carpio in Mexico due to the metacercariae of Centocestus formosonus. J. Fish Dis. 21:229-32.

Hong, SJ, Seo, BS, Lee, SH, Chai, JY, 1988: A human case of Centrocestus armatus infection in Korea. Korean J. Parasitol. 26:55-60.

Pritchard, MH, Kruse, GO, 1982: The collection and preservation of animal parasites. Tech. Bull. No. 1. The Harold W. Manter Laboratory, University of Nebraska Press,

Mahdy, OA, Manal, AA, Essa, AA, Easa, M, 1995: Parasitological and pathological studies on Heterophyid infection in Tilapia species from Manzala Lake, Egypt. Vet. Med. J. Comp. Pathol. Clin. Pathol. 8, 2:131-45.

Mahdy, OA, Mousa, WM, Kandil, OM, 2000: Some serological and biological control on Heterophyes heterophyes and Prohemistomum vivax in experimentally infected rates. Assuit Vet. Med. J. 43, 85:186-98.

Mahmoud, NAM, Sahlab, AAM, 1993: Clinostomiasis (yellow grub disease) in Tilapia nilotica and galilae in High Dam Lake, with relation to public health importance in Egypt. Egypt. J. Agric. Res. 71, 3:825-34.

Mousa, WM, Mahdy, OA, Kandil, OM, 2000: Electrophoretic analysis to confirm the identification of some kinds of encysted metacercariae from Oreochromis niloticus. Assiut Vet. Med. J.
Paperna, I, 1980: Parasitic infection and diseases of fish in Africa. F.A.O CIFA Tech. Paper 7:51-62.

Park, CW, Kim, JS, Joo, HS, Kim, J, 2009: A human case of Clinostomum complanatum infection in Korea. Korean J. Parasitol. 47, 4:401-4.

Saleh, RS, Abou-Eisha, AM, Fadel, HM, Helmy, YA, 2009: Occurrence of encysted metacercariae of some zoonotic trematodes in freshwater fishes and their public health significance in Port Said province. Proc. $2^{\text {nd }}$ Global Fisheries and Aquaculture Res. Conf., Cairo Inter. Convention Center, 24-26 October, Egypt.

Srisawangwong, T, Pinlaor, S, Kanla, P, Sithithaworn, P, 1997: Centrocetus formosanus surface morphology of metacercaia adult and egg. J. Helminthol. 71:345-50.

Taher, GA, 2009: Some studies on metacercarial infection in $O$. niloticus in Assiut Governorate and their role in transmission of some trematodes to dogs. Assiut Univ. Bull. Environ. Res. 12, 1:63-79.

Wehab, HH, Abo-Esa, JFK, 2002: Study on the relationship between the bioaccumulation of heavy metals in the fish muscle and fish parasitism in Qaroun Lake. J. Egypt. Vet. Med. Assoc. 62, 5:245-57.

WHO, 1995: Control of Foodborne Trematode Infections. Tech. Report. Ser. No. 849, Geneva

Williams, HH, Jones, A, 1976: Marine helminthes and human health. Commonu. Inst. Helminthol. Misc. Publication.

Yamaguti, S, 1971: Synopsis of Digenetic Trematodes of Vertebrates. Vols. I \& II. Tokyo, Japan: Keigaku Publishing Company.

43, 85:199-209.

\section{Explanation of figures}

Fig. 1: a-Cyathocotyidae EMC in O. niloticus, b- Cyathocotyidae EMC of C. gariepenus (scale bar $0.1 \mathrm{~mm}$ )

Fig. 2: Cynodiplostomatidae in muscles of $C$. gariepenus (scale bar $0.1 \mathrm{~mm}$ )

Fig. 3: Heterophydae EMC in gill filaments of $O$. niloticus (scale bar $0.1 \mathrm{~mm}$ )

Fig. 4; Diplostomatidae EMC in O. niloticus (scale bar $0.2 \mathrm{~mm}$ ),

Fig. 5: Adult Centrocetus armatus recovered from experimentally infected rat (scale bar $0.1 \mathrm{~mm}$ ),

Fig. 6: Adult Mesostephanus appendiculatus recovered from experimentally infected pigeon \& rat (scale bar $0.2 \mathrm{~mm}$ ),

Fig. 7: Adult Promehistomum vivax recovered from experimentally infected pigeon \& rat (scale bar $0.2 \mathrm{~mm}$ ),

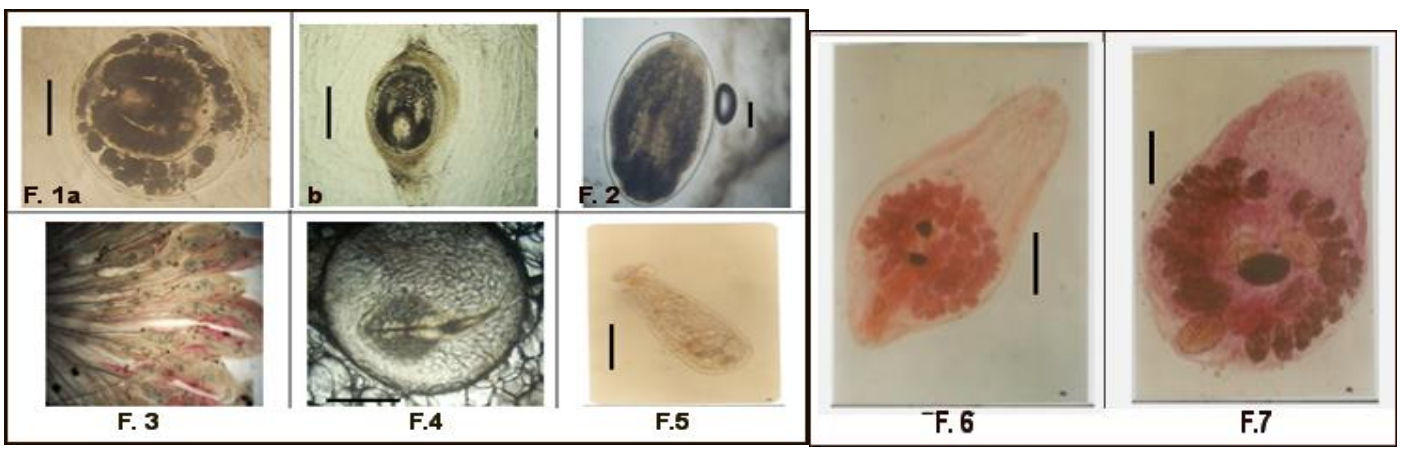

